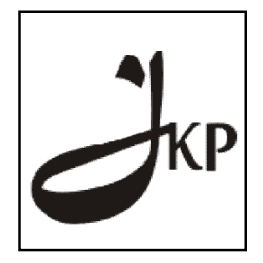

Jurnal Konseling dan Pendidikan

ISSN Cetak: 2337-6740 - ISSN Online: 2337-6880

http://jurnal.konselingindonesia.com

Volume 3 Nomor 3, November 2015, HIm 13-20

Info Artikel:

Diterima 14/10/2015

Direvisi 10/11/2015

Dipublikasikan 28/11/2015

\title{
MENINGKATKAN HASIL BELAJAR SISWA MELALUI METODE BELAJAR KELOMPOK PADA MATA PELAJARAN IPS KELAS VI SD NEGERI 35 KAMPUNG SAWAH KECAMATAN KOTO XI TARUSAN TAHUN PELAJARAN 2013/2014
}

\section{ANDRI, S.Pd.SD}

\section{Abstrak}

Fungsi pelajaran Ilmu Pengetahuan Sosial (IPS) di Sekolah Dasar adalah untuk mengembangkan sikap rasional tentang gejala-gejala sosial serta wawasan tentang perkembangan masyarakat Indonesia dan dunia di masa lampau dan masa kini. Rumusan masalah dalam penelitian ini adalah Bagaimanakah metode belajar kelompok dapat meningkatkan hasil belajar dan aktivitas belajar siswa dalam mata pelajaran IPS di Kelas VI SD Negeri 35 Kampung Sawah Kecamatan Koto XI Tarusan Tahun Pelajaran 2013/2014?Tujuan penelitian ini untuk mengetahui dan memperoleh gambaran tentang sejauh mana metoda belajar kelompok dapat meningkatkan hasil belajar dan aktivitas siswa pada mata pelajaran IPS di Kelas VI SD Negeri 35 Kampung Sawah Kecamatan Koto XI Tarusan Tahun Pelajaran 2013/2014.Penelitian ini adalah Penelitian Tindakan Kelas (PTK) pada siswa SD Negeri 35 Kampung Sawah Kecamatan Koto XI Tarusan.Hasil penelitian menunjukan peningkatan hasil belajar siswa.Siswa yang aktif juga mengalami peningkatan.Siswa juga berpendapat bahwa pembelajaran ini dapat meningkatkan keterampilan mereka untuk berpendapat dan menyelesaikan masalah.

Keyword: Hasil Belajar, Metode Belajar Kelompok, Pembelajaran IPS

Copyright (C) 2015 IICET (Padang - Indonesia) - All Rights Reserved

Indonesian Institute for Counseling, Education and Theraphy (IICET)

\section{PENDAHULUAN}

Fungsi mata pelajaran Ilmu Pengetahuan Sosial (IPS) di Sekolah Dasar adalah untuk mengembangkan sikap rasional tentang gejala-gejala sosial serta wawasan tentang perkembangan masyarakat Indonesia dan dunia di masa lampau dan masa kini. Sedangkan tujuan mata pelajaran IPS di Sekolah Dasar adalah untuk mendapatkan pengetahuan dan keterampilan dasar yang berguna bagi siswa dalam kehidupan sehari-hari serta mampu mengembangkan pemahaman tentang perkembangan masyarakat Indonesia sejak masa lalu hingga masa kini, sehingga siswa memilki kebanggaan sebagai bangsa Indonesia dan cinta kepada tanah air (Depdikbud,1999).Pencapaian fungsi dan tujuan mata pelajaran IPS di Sekolah Dasar penting untuk dilaksanakan oleh guru dalam proses pembelajaran.Hal ini dilakukan dengan menerapkan prinsip-prinsip pembelajaran IPS sebagaimana tercantum dalam GBPP IPS Sekolah Dasar Tahun 1999 yaitu pembelajaran dimulai dengan sesuatu yang sederhana dan dekat dengan kehidupan nyata anak ke arah pembelajaran yang luas dan kompleks. Pembelajaran yang dilaksanakan harus melibatkan mental, fisik dan sosial anak yang sesuai dengan perkembangannya(Depdikbud:1999: 122-123).

Pembelajaran IPS di SD memiliki cakupan materi yang luas dan alokasi waktu yang terbatas membuat guru mengalamikesulitan dalam melaksanakan pembelajaran yang menarik, dan menantang minat belajar siswa.Pembelajaran IPS yang dilaksanakan di Kelas VI SD Negeri 35 Kampung Sawah Kecamatan Koto XI Tarusan Tahun Pelajaran 2013/2014 adalah dengan melakukan pembelajaran untuk mengejar target.Hal ini menyebabkan pembelajaran hanya terpaku pada sumber yang tersedia.Metode yang digunakan dalam pembelajaran biasanya menggunakan metode ceramah sehingga kurang dapat melibatkan siswa secara aktif dalam belajar.Metode ceramah ini kurang dapat membantu siswa untuk memiliki kompetensi sosial. Pemberian contoh untuk memperjelas materi pembelajaran kurang dekat dengan kehidupan nyata siswa.

Salah satu metode pembelajaran yang dapat melibatkan siswa secara aktif dan membantu siswa mengembangkan kompetensi sosial dalam pembelajaran IPS adalah metode belajar berkelompok. Siswa yang dilibatkan secara aktif dalam kegiatan pembelajaran IPS akan memberi makna dan mendorong siswa belajar lebih 
lanjut.Melalui belajar secara berkelompok siswa dilatih untuk kreatif memecahkan masalah secara bersama-sama, melatih kepemimpinan, melatih rasa percaya diri dan menghargai orang lain. Lingkungan belajar yang diciptakan dengan berbagai interaksi seperti interaksi siswa dengan siswa, guru dengan siswa, dan siswa dengan sumber belajar akan sangat potensial untuk dapat membimbing siswa mengembangkan pengetahuannya.

Berdasarkan penjelasan di atas dilakukan penelitian tindakan kelas menggunakan metode belajar kelompok pada mata pelajaran IPS di Kelas VI SD Negeri 35 Kampung Sawah Kecamatan Koto XI Tarusan Tahun Pelajaran 2013/2014.Rumusan masalah dalam penelitian ini adalah Bagaimanakah metode belajar kelompok dapat meningkatkan hasil belajar dan aktivitas belajar siswa dalam mata pelajaran IPS di Kelas VI SD Negeri 35 Kampung Sawah Kecamatan Koto XI Tarusan Tahun Pelajaran 2013/2014?Tujuan penelitian ini untuk mengetahui dan memperoleh gambaran tentang sejauh mana metoda belajar kelompok dapat meningkatkan hasil belajar dan aktivitas siswa pada mata pelajaran IPS di Kelas VI SD Negeri 35 Kampung Sawah Kecamatan Koto XI Tarusan Tahun Pelajaran 2013/2014.

\section{METODOLOGI PENELITIAN}

Penelitian ini merupakan penelitian Tindakan Kelas (PTK) yang mengacu kepada tindakan guru ketika melaksanakan kegiatan belajar mengajar sebagai upaya untuk memperbaiki kegiatan belajar mengajar berdasarkan refleksi dari kegiatan belajar mengajar tersebut.Desain Penelitian Tindakan Kelas dirancang untuk dapat menyelesaikan satu pokok bahasan yang, akan dilaksanakan secara berkelanjutan dengan menggunakan dua siklus. Setiap siklus akan dilaksanakan sesuai dengan perubahan atau perbaikan pembelajaran yang ingin dicapai seperti yang digambarkan pada pertanyaan penelitiannya. Desain penelitian yang dirancang terdiri dari (a) perencanaan tindakan, (b) pelaksanaan tindakan. (c) observasi/refleksi, dan (d) perencanaan tindakan lanjutan (Depdikbud: 1999; Kasbolah:1998). Subjek penelitian adalah siswa kelas Kelas VI SD Negeri 35 Kampung Sawah Kecamatan Koto XI Tarusan Tahun Pelajaran 2013/2014.

\section{HASIL DAN PEMBAHASAN \\ HASIL PENELITIAN \\ Siklus I \\ Perencanaan}

Pada kegiatan awal, guru mengkondisikan siswa ke arah situasi belajar kondusif, mengabsen; mengadakan tanya jawab sebagai bahan pengait (apersepsi). Kegiatan intiterdiri dari: Siswa mendengarkan penjelasan guru tentang kegiatan dikusi bersama dalam kelompok yang akan dilakukan;Siswa menyimak sedikit cerita yang mengarah kepada pengertian globalisasi; membagi siswa menjadi delapan kelompok, masing-masing kelompok terdiri dari 3 sampai 4 orang siswa;Tiap-tiap kelompok diberi lembar LKS;Dalam kelompok siswa belajar bersama untuk menyelesaikan soal-soal yang ada di dalam LKS;Setiap siswa dalam kelompok menuliskan hasil jawaban dalam lembar kegiatan siswa yang telah disediakan;Tiap kelompok menyimpulkan hasil jawaban;Wakil dari setiap kelompok membacakan hasil jawaban di depan kelas satu persatu, sementara siswa lain menyimak dan menanggapi hasil jawaban teman lainnya;Guru mengumpulkan lembar hasil kegiatan siswa;Siswa diberi kesempatan untuk bertanya tentang hal-hal yang belum dimengerti;Kegiatan akhir terdiri dari: siswa menjawab soal-soal yang diberikan oleh guru secara tertulis; Guru menyimpulkan seluruh kegiatan belajar yang telah dilakukan.

\section{Pelaksanaan Tindakan}

Pelaksanaan pembelajaran pada siklus pertama ini tentang "Dampak Globalisasi". Pada pelaksanaan tindakan pertama langkah-langkah yang ditempuh disesuaikan dengan apa yang tercantum dalam rencana pengajaran yang telah dibuat sebelumnya. Langkah-langkah yang dilakukan sebagai berikut.

- Siswa berdo'a dan memberi salam kepada guru, guru mengabsen siswa, dari 22 siswa, dan seluruh siswa hadir semua.

- Guru memberikan arahan dan penjelasan kepada siswa untuk membentuk kelompok yang setiap kelompoknya tidak lebih dari 3 orang siswa. Dalam pengarahan tersebut siswa diberi kebebasan untuk memilih teman kelompoknya.

- Dalam memilih dan menentukan teman untuk belajar secara kelompok, kebanyakan siswa memilih berdasarkan tempat duduk yang berdekatan dengan dirinya, sehingga teman sebangkunya menjadi teman kelompoknya. 
- Setelah seluruh siswa yang hadir dengan jumlah 22 orang siswa tersebut, maka terbentuklah 7 kelompok. Mereka terlihat senang dengan raut muka yang berseri-seri karena mendapatkan teman untuk belajar secara berkelompok.

- Karena tak seperti biasa, mereka tampak antusias dan bersemangat untuk memulai pelajaran ketika guru memberi penjelasan tentang materi IPS yang akan dipelajari.

- Dalam menyelesaikan dan menjawab LKS, mereka betul-betul bekerja sama dan serius dalam kelompoknya. Dan tidak mau ketinggalan dengan kelompok lainnya.

- Guru berkeliling ke kelompok-kelompok, sambil membimbing, mengarahkan dan membantu siswa (kelompok) yang kesulitan menyelesaikan LKS-nya.

- Guru mengumpulkan LKS dari setiap kelompok. Kemudian membagikan lembar evaluasi (tes) kepada setiap siswa untuk mengukur sejauh mana siswa dapat memahami materi yang telah dipelajari secara berkelompok.

- Setelah setiap kelompok selesai mengerjakan lembar evaluasi (tes), guru mengumpulkannya, kemudian membagikan daftar cek kepada siswa untuk melihal persepsi siswa tentang kegiatan belajar mengajar yang telah mereka alami.

Pengamatan dan Refleksi

Data dan informasi yang diperoleh dari kelompok belajar siswa dalam mengerjakan LKS pada siklus I adalah sebagai berikut:

Tabel 1

Prosentasi Hasil Kerja Kelompok dalam Mengerjakan LKS

\begin{tabular}{|c|c|c|c|c|c|c|}
\hline \multirow{2}{*}{ Kelompok } & \multicolumn{7}{|c|}{ Jawaban Soal LKS } \\
\cline { 2 - 7 } & Benar & $\%$ & Salah & $\%$ & $\begin{array}{c}\text { Tidak } \\
\text { tepat }\end{array}$ & $\%$ \\
\hline 1 & 3 & $60,00 \%$ & 2 & $40,00 \%$ & 0 & $0,00 \%$ \\
\hline 2 & 4 & $80,00 \%$ & 0 & $0,00 \%$ & 1 & $20,00 \%$ \\
\hline 3 & 3 & $60,00 \%$ & 1 & $20,00 \%$ & 1 & $20,00 \%$ \\
\hline 4 & 2 & $40,00 \%$ & 1 & $1,00 \%$ & 3 & $60,00 \%$ \\
\hline 5 & 2 & $40,00 \%$ & 2 & $40,00 \%$ & 1 & $20,00 \%$ \\
\hline 6 & 3 & $60,00 \%$ & 2 & $40,00 \%$ & 0 & $0,00 \%$ \\
\hline 7 & 4 & $80,00 \%$ & 0 & $0,00 \%$ & 1 & $20,00 \%$ \\
\hline \multicolumn{2}{|c|}{ Prosentasi } & $60,00 \%$ & & $20,14 \%$ & & $20,00 \%$ \\
\hline
\end{tabular}

Berdasarkan hasil pekerjaan kelompok dalam mengerjakan LKS pada pelaksanaan siklus I ini ternyata bahwa prosentasi kelompok yang dapat mengerjakan LKS dengan benar adalah 60,0\%. Sementara kelompok yang belum dapat mengerjakan LKS dengan benar adalah 20,14\%. Sedangkan kelompok yang kurang tepat dalam mengisi LKS adalah 20,00\%. Bila menunjuk pada tabel 1 di atas penerapan metoda belajar secara berkelompok juga dapat mencapai tujuan pembelajaran tanpa didominasi guru dalam kegiatan belajar mengajamya.

\section{Siklus II}

\section{Perencanaan}

Pada kegiatan awal, guru mengkondisikan siswa ke arah situasi belajar kondusif, mengabsen; mengadakan tanya jawab sebagai bahan pengait (apersepsi). Kegiatan intiterdiri dari: Siswa mendengarkan penjelasan guru tentang kegiatan dikusi bersama dalam kelompok yang akan dilakukan;Siswa menyimak sedikit cerita yang mengarah kepada pengertian globalisasi; membagi siswa menjadi delapan kelompok, masing-masing kelompok terdiri dari 3 sampai 4 orang siswa;Tiap-tiap kelompok diberi lembar LKS;Dalam kelompok siswa belajar bersama untuk menyelesaikan soal-soal yang ada di dalam LKS;Setiap siswa dalam kelompok menuliskan hasil jawaban dalam lembar kegiatan siswa yang telah disediakan;Tiap kelompok menyimpulkan hasil jawaban;Wakil dari setiap kelompok membacakan hasil jawaban di depan kelas satu persatu, sementara siswa lain menyimak dan menanggapi hasil jawaban teman lainnya;Guru mengumpulkan lembar hasil kegiatan siswa;Siswa diberi kesempatan untuk bertanya tentang hal-hal yang belum dimengerti;Kegiatan akhir terdiri dari: siswa menjawab soal-soal yang diberikan oleh guru secara tertulis; Guru menyimpulkan seluruh kegiatan belajar yang telah dilakukan. 


\section{Pelaksanaan}

Pelaksanaan siklus II merupakan aktualisasi dari rencana pembelajaran yang telah dirumuskan dan disiapkan sebelumnya berdasarkan hasil pengamatan dan refleksi dari pelaksanaan tindakan pertama.Pelaksanaan siklus II ini materi ajarnya adalah tentang "Latar belakang berdirinya perusahaan asing".Pelaksanaan pembelajaran sebagai berikut:

-Siswa berdo'a dan memberi salam kepada guru, kemudian guru mengabsen, dari 22 jumlah siswa, yang hadir 22 , sama halnya dengan tindakan pertama

- Guru memberikan pengarahan untuk setiap kelompok tidak lebih dari 3 orang. Pemilihan teman untuk kelompok diserahkan sepenuhnya kepada siswa, dan apabila memungkinkan dalam kelompok itu ada teman dari jenis kelamin yang berbeda.Namun nampaknya dalam memilih teman kelompok dengan jenis kelamin yang berbeda para siswa belum siap.

- Seperti halnya pada tindakan pertama, para siswa memilih teman kelompok berdasarkan tempat duduk yang berdekatan. Dengan bantuan guru akhirnya seluruh siswa dapat tertampung di dalam kelompok belajar walaupun tidak ada satu kelompok pun yang anggotanya berlainan jenis kelamin.

- Dari 22 siswa yang hadir, terbentuk 7 kelompok. Kemudian guru memberikan LKS yang berupa soal kegiatan Latar belakang berdirinya perusahaan asing untuk pelaksanaan tindakan kedua ini. Setiap kelompok ditugasi untuk membahsa dan menyelesaikan LKS berkenaan dengan sub pokok bahasan tentang menceritakan tentang Latar belakang berdirinya perusahaan asing.

- Dalam menyelesaikan dan menjawab LKS, siswa dalam kelompok betul-betul bekerja satu sama lain bahu membahu dan serius untuk bisa menjawab dan mengisi LKS.

- Seperti halnya pada tindakan pertama, guru berkeliling sambil membimbing, mengarahkan dan membantu siswa yang mengalami kesulitan dalam mengerjakan dan meyelesaikan LKS.

- Selesai mengerjakan LKS guru mengumpulkannya, guru membagikan lembar evaluasi kepada siswa untuk mengetes kemampuan siswa dalam memahami pelajaran yang sudah dipelajari. Guru membagikan daftar cek kepada setiap siswa untuk melihat persepsi siswa tentang kegiatan belajar secara berkelompok yang telah dilaksanakan.

\section{Pengamatan dan Refleksi}

Setelah guru melakukan tindakan kedua dengan menerapkan metoda tentang belajar secara berkelompok dalam mata pelajaran IPS dengan sub pokok bahasan tentang Latar belakang berdirinya perusahaan asing dalam kehidupan sehari-hari, guru melakukan analisis dan refleksi terhadap pelaksanaan tindakan kedua berdasarkan data dan informasi yang berhasil dihimpun. Prosentasi hasil kelompok dalam mengerjakan LKS dapat dilihat pada tabel 2 dengan didasarkan atas standar penilaian bahwa kelompok yang benar dalam menyelesaikan LKS diberi bobot 100\%.Kelompok yang belum dapat menyelesaikan dengan benar diberi bobot sesuai dengan tingkat kebenarannya, misalnya $50 \%$ apabila pengisiannya dianggap setengah $(1 / 2)$ benar, $75 \%$ apabila pengisiannya dianggap tiga per empat $(3 / 4)$ benar.

Tabel 2

Prosentasi Hasil Kerja Kelompok dalam Mengerjakan LKS

\begin{tabular}{|c|c|c|c|c|c|c|}
\hline \multirow{2}{*}{ Kelompok } & \multicolumn{7}{|c|}{ Jawaban Soal LKS } \\
\cline { 2 - 7 } & Benar & $\mathbf{\%}$ & Salah & \% & Tidak tepat & $\%$ \\
\hline 1 & 2 & $66,67 \%$ & 0 & $0,00 \%$ & 1 & $33,33 \%$ \\
\hline 2 & 2 & $66,67 \%$ & 0 & $0,00 \%$ & 1 & $33,33 \%$ \\
\hline 3 & 2 & $66,67 \%$ & 1 & $33,33 \%$ & 0 & $0,00 \%$ \\
\hline 4 & 2 & $66,67 \%$ & 1 & $33,33 \%$ & 0 & $0,00 \%$ \\
\hline 5 & 1 & $33,33 \%$ & 1 & $33,33 \%$ & 1 & $33,33 \%$ \\
\hline 6 & 2 & $66,67 \%$ & 0 & $0,00 \%$ & 1 & $33,33 \%$ \\
\hline 7 & 2 & $66,67 \%$ & 1 & $33,33 \%$ & 0 & $0,00 \%$ \\
\hline \multicolumn{2}{|c|}{ Prosentasi } & $61,91 \%$ & & $19,05 \%$ & & $19,05 \%$ \\
\hline
\end{tabular}


Penilaian hasil belajar siswa didasarkan atas standar penilaian jawaban terhadap soal tes yang berjumlah 3 butir.Setiap butir soal apabila dijawab dengan benar diberi nilai 2 (dua), sedangkan jawaban yang kurang tepat diberi nilai 1 (satu), dan jawaban yang salah diberi nilai 0 (nol).Penerapan metoda belajar secara berkelompok cukup efektif untuk mencapai tujuan pembelajaran IPS di Kelas VI SD Negeri 35 Kampung Sawah Kecamatan Koto XI Tarusan Tahun Pelajaran 2013/2014.Terbukti dengan hasil tes yang telah dicapai siswa. Prosentasi daya serap siswa dalam sub pokok bahasan tentang "Latar belakang berdirinya perusahaan asing "cukup tinggi". Hal ini terlihat pada table 3 berikut.

Tabel 3

Prosentasi Perolehan Nilai Hasil Belajar Pada Siklus I dan Siklus II

\begin{tabular}{|c|c|c|c|}
\hline No Soal & Nilai & Siklus I & Siklus II \\
\hline \multirow{3}{*}{1} & 2 & $54,05 \%$ & $91,89 \%$ \\
& 1 & $2,7 \%$ & $5,41 \%$ \\
& 0 & $43,24 \%$ & $2,7 \%$ \\
\hline \multirow{2}{*}{2} & 2 & $75,68 \%$ & $78,38 \%$ \\
& 1 & $8,11 \%$ & $16,22 \%$ \\
& 0 & $16,22 \%$ & $5,41 \%$ \\
\hline \multirow{3}{*}{3} & 2 & $72,97 \%$ & $81,08 \%$ \\
& 1 & $2,7 \%$ & $13,51 \%$ \\
\hline \multirow{3}{*}{4} & 0 & $24,32 \%$ & $5,41 \%$ \\
& 2 & $70,27 \%$ & \\
\hline \multirow{2}{*}{5} & 1 & $5,41 \%$ & \\
& 0 & $24,32 \%$ & \\
& 1 & $64,85 \%$ & \\
\hline
\end{tabular}

Berdasarkan tabel di atas menunjukan bahwa pada siklus I siswa yang mendapat nilai 2 atau jawaban siswanya "benar" mencapai $67,57 \%$ dari 22 siswa yang mengikuti tes. Sementara siswa yang mendapat nilai 1 atau menjawab "kurang tepat" prosentasinya mencapai 4,87\%. Sedangkan siswa yang mendapat nilai 0 (nol) atau "salah" prosentasinya $27,57 \%$. Pada silkus II, siswa yang mencapat nilai 2, perolehan nilai hasil belajar siswa meningkat menjadi $8378 \%$. Sementara itu siswa yang mendapat nilai 1 atau "kurang tepat" meningkat dari sebanyak 4,87\% menjadi $11,71 \%$, sedangkan yang mendapat 0 (nol) menurun dari $27,57 \%$ menjadi $1 \%$.

Aktivitas belajar siswa dalam mata pelajaran IPS yang menerapkan metoda belajar secara berkelompok diperoleh melalui instrumen observasi aktivitas belajar siswa yang telah disiapkan dalam upaya untuk mengungkap dan mengetahui aktivitas belajar siswa selama pelaksanaan pembelajaran.Siklus I, setelah setiap kelompok mendapatkan LKS, mereka membahas dan meyelesaikan LKS dengan merujuk pada arti tindakan ekonomi tersebut.Pada mulanya hampir seluruh siswa hening sambil memperhatikan soal yang ada di LKS tersebut sambil memperhatikan penjelasan guru. Namun beberapa saat kemudian siswa mulai berinteraksi sesama anggota kelompoknya, ada yang memperhatikan dan membaca apa tujuan dari soal yang dimaksud, ada siswa yang memegang dan memperhatikan LKS, dan ada juga siswa yang membuka-buka buku IPS, serta ada juga yang memegang sambil memperhatikan dan mengamati gambar yang ada di LKS. Tentunya mereka selama melakukan aktivitas tersebut tidak diam saja, tetapi mereka melakukan kegiatan tersebut sambil bercakap-cakap dan berinteraksi satu sama lainnya. Dalam menyelesaikan dan menjawab LKS, siswa membantu satu sama lain untuk dapat menjawab soal-soal yang terdapat dalam LKS, tidak mau ketinggalan dengan kelompok lainnya. Aktivitas siswa dalam belajar adalah melahirkan interaksi dengan sesama teman untuk dapat menyelesaikan LKS dengan merujuk pada obyek untuk diamati dan juga terlibat sumber belajar lain yaitu buku sumber IPS Kelas VI untuk dapat menyelesaikan LKS. Sementara aktivitas guru memfasilitasi dan membantu siswa dengan berkeliling dari satu kelompok ke kelompok yang lain sambil mengarahkan dan membantu kelompok yang kesulitan menjawab LKS.

Siklus II, guru memberikan LKS berupa gambar yang terjadi dalam kehidupan sehari-hari yang berhubungan dengan pokok bahasan kepada 22 orang siswa yang hadir. Seperti halnya pada siklus I buku IPS 
Kelas VI menjadi buku sumber pada pokok bahasan tentang Globalisasi, dan guru berkeliling untuk mengarahkan dan membantu kelompok yang kesulitan dalam mengisi LKS.Berikut adalah tabel yang menunjukan aktivitas belajar siswa dalam mata pelajaran IPS yang menerapkan metode belajar secara berkelompok selama pelaksanaan tindakan I dan II.

Tabel 4

Prosentase aktivitas Belajar Siswa Pada Siklus I dan II

\begin{tabular}{|c|l|c|c|c|c|c|c|c|c|}
\hline \multirow{2}{*}{ No } & \multirow{2}{*}{$\begin{array}{c}\text { Aktivitas Belajar } \\
\text { Siswa }\end{array}$} & \multicolumn{4}{|c|}{ Siklus I } & \multicolumn{3}{|c|}{ Sikks II } \\
\cline { 2 - 9 } & tinggi & Tinggi & Sedang & Rendah & $\begin{array}{c}\text { Sangat } \\
\text { tinggi }\end{array}$ & Tinggi & Sedang Rendah \\
\hline 1 & Disiplin & $0 \%$ & $75,86 \%$ & $24,32 \%$ & $0 \%$ & $24,32 \%$ & $75,68 \%$ & $0 \%$ & $0 \%$ \\
\hline 2 & $\begin{array}{l}\text { Motivasi/Semangat } \\
\text { belajar }\end{array}$ & $8,11 \%$ & $56,76 \%$ & $32,43 \%$ & $2,7 \%$ & $21,62 \%$ & $78,38 \%$ & $0 \%$ & $0 \%$ \\
\hline 3 & Perhatian Siswa & $10,81 \%$ & $56,76 \%$ & $29,73 \%$ & $2,7 \%$ & $13,51 \%$ & $83,78 \%$ & $2,7 \%$ & $0 \%$ \\
\hline 4 & Komunikasi Siswa & $5,41 \%$ & $78,38 \%$ & $16,22 \%$ & $0 \%$ & $13,51 \%$ & $86,49 \%$ & $0 \%$ & $0 \%$ \\
\hline 5 & Kerjasama Siswa & $24,32 \%$ & $64,86 \%$ & $8,11 \%$ & $0 \%$ & $27,03 \%$ & $86,49 \%$ & $0 \%$ & $0 \%$ \\
\hline 6 & $\begin{array}{l}\text { Aktivitas Belajar } \\
\text { Individu }\end{array}$ & $18,92 \%$ & $40,54 \%$ & $37,84 \%$ & $0 \%$ & $29,73 \%$ & $67,57 \%$ & $2,7 \%$ & $0 \%$ \\
\hline 7 & $\begin{array}{l}\text { Aktivitas Belajar } \\
\text { Kelompok }\end{array}$ & $29,73 \%$ & $67,57 \%$ & $2,7 \%$ & $0 \%$ & $62,16 \%$ & $37,84 \%$ & $0 \%$ & $0 \%$ \\
\hline 8 & $\begin{array}{l}\text { Tanggungjawab } \\
\text { Siswa }\end{array}$ & $5,41 \%$ & $83,78 \%$ & $8,11 \%$ & $0 \%$ & $16,22 \%$ & $83,78 \%$ & $0 \%$ & $5,41 \%$ \\
\hline
\end{tabular}

Pada siklus I, prosentasi siswa yang menunjukan aktivitas "disiplin" tinggi sebesar 75,68\%, "sedang" 24,32\%. Pada prosentasi siswa yang motivasi/semangat belajarnya "sangat tinggi" sebesar 8,11\%, "tinggi" $56,76 \%$, "sedang" 32,43\% dan "rendah" 2,70\%. Aktivitas siswa yang menunjukan perbaikan siswa "sangat tinggi" adalah sebesar 10,81\%, "tinggi" 56,76\%, "sedang" 29,73\% dan 2,70\% pada perhatiannya "rendah". Pada komunikasi yang menunjukan "sangat tinggi" prosentasinya 5,41\%, "tinggi" sebesar 78,38\% dan "sedang" $16,22 \%$. Sementara aktivitas belajar siswa yang menunjukan kerja sama yang "sangat tinggi" prosentasinya adalah 24,32\%, "tinggi" 64,86\%, "sedang" sebesar 8,11\%, sedangkan prosentasi siswa yang menunjukan aktivitas belajar individunya "sangat tinggi" sebesar 40,54\%, "sedang" sebesar 37,84\%, sementara aktivitas belajar kelompoknya "sangat tinggi" prosentasinya sebesar 29,73\%, "tinggi" 67,57\%, "sedang" hanya sebesar 2,70\%. Aktivitas belajar siswa yang bertanggung jawab "srngat tinggi" sebesar 5,41\%, "tinggi" sebesar 83,78\% dan "sedang" hanya 8,11\%.

Pada Siklus II, prosentasi siswa yang menunjukan aktivitas disiplin "sangat tinggi" sebesar $24,32 \%$, "tinggi" sebesar 75,68\%. Pada prosentasi siswa yang motivasi/semangat yang menunjukan "sangat tinggi" sebesar 21,62\%, "tinggi" 78,38\%. Aktivitas siswa yang perhatian siswa "sangat tinggi" adalah sebesar 13,51\%, "tinggi" $83,78 \%$, "sedang" 2,70\%. Pada komunikasi yang menunjukan "sangat tinggi" prosentasinya 13,51\%, "tinggi" sebesar $86,49 \%$. Sementara aktivitas belajar siswa yang menunjukan kerja sama yang "sangat tinggi" prosentasinya adalah $27,03 \%$, "tinggi" $86,49 \%$. Sedangkan prosentasi siswa yang menunjukan aktivitas belajar individunya "sangat tinggi" sebesar 29,73\%, "tinggi 67,57\%, dan prosentasi "sedang" sebesar 2,70\%, sementara aktivitas belajar kelompoknya "sangat tinggi" prosentasinya sebesar 62,16\%, "tinggi" 37,84\%. Aktivitas belajar siswa yang bertanggung jawab "sangat tinggi" sebesar 16,22\%, "tinggi" sebesar 83,78\%.

Dari pelaksanaan penelitian siklus I dan II terungkap pendapat dan sikap siswa dari daftar cek yang dibagikan dan diisi oleh seluruh siswa yang hadir, aspek-aspek yang berkenaan dengan keterampilan-keterampilan yang dapat dikembangkan siswa ketika belajar bersama dalam kelompok.Tabel 5 di bawah ini adalah prosentasi jawaban siswa terhadap daftar cek yang di dalamnya mengandung aspek-aspek tentang keterampilan-keterampilan yang dapat dikembangkan siswa ketika siswa belajar secara berkelompok. 
Tabel 5

Prosentasi Jawaban Siswa Terhadap Daftar Cek Pada Siklus I dan Siklus II

\begin{tabular}{|c|c|c|c|c|c|c|c|}
\hline \multirow[b]{2}{*}{ No } & \multirow[b]{2}{*}{ Aspek Yang Dikembangkan } & \multicolumn{3}{|c|}{ Siklus I } & \multicolumn{3}{|c|}{ Siklus II } \\
\hline & & 少 & 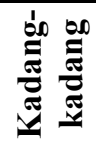 & $\frac{\Xi}{\frac{\Xi}{\sigma}}$ & 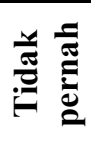 & 卣 & $\frac{\Xi}{\frac{\pi}{D}}$ \\
\hline 1 & $\begin{array}{l}\text { Menyampaikan pendapat dalam } \\
\text { kegiatan belajar secara berkelompok }\end{array}$ & 0 & 21,62 & 78,38 & 0 & 8,11 & 91,89 \\
\hline 2 & $\begin{array}{l}\text { Pendapat siswa yang salah dijawab } \\
\text { oleh teman anggota kelompoknya }\end{array}$ & 27,03 & 43,24 & 29,73 & 16,22 & 45,95 & 37,84 \\
\hline 3 & $\begin{array}{l}\text { Berbagi pengalaman dengan sesama } \\
\text { anggota kelompok }\end{array}$ & 5,41 & 27,03 & 67,57 & 0 & 16,22 & 83,78 \\
\hline 4 & $\begin{array}{l}\text { Menyelesaikan tugas sesuai dengan } \\
\text { waktu yang diberikan }\end{array}$ & 10,31 & 37,84 & 51,35 & 0 & 16,22 & 83,78 \\
\hline
\end{tabular}

Pada siklus I dari 22 orang siswa yang hadir, mereka menjawab "selalu" menyampaikan pendapatnya ketika belajar secara berkelompok, prosentasinya adalah 78,38\%. Sementara yang menjawab "kadang-kadang" prosentasinya $21,26 \%$, dan yang menjawab "tidak pernah" prosentasinya $0 \%$. Dengan perolehan prosentasi sebesar ini, siswa selama belajar bersama dalam kelompok dapat mengembangkan keterampilan dalam menyampaikan pendapat. Selain itu juga siswa mendapat keterampilan lain yaitu menghargai pendapat orang lain, walaupun pendapat itu salah. Karena dalam daftar cek yang dibagikan kepada siswa terdapat pertanyaan tentang "pendapat siswa yang salah dijawab oleh teman anggota kelompoknya". Jawaban siswa terhadap pertanyaan ini adalah "selalu" prosentasinya 29,73\%, "kadang-kadang" 43,24\% dan "tidak pernah" prosentasinya 27,03\%.

Sementara itu aspek keterampilan berbagi pengalaman dengan sesama anggota kelompok yang menjawab "selalu" adalah 67,57\%, "kadang-kadang" 27,03\% dan menjawab "tidak pernah" 5,41\%. Sedangkan aspek keterampilan menyelesaikan tugas sesuai waktu yang diberikan, siswa yang menjawab selalu prosentasinya 51,35\% yang menjawab "kadang-kadang" 37,84\% dan menjawab "tidak pernah" prosentasinya adalah 10,81 \%.

Pada siklus II pendapat dari 22 orang siswa yang hadir siswa menjawab "selalu" menyampaikan pendapatnya ketika belajar secara berkelompok.prosentasinya adalah 91,89\%. Sementara yang menjawab "kadang-kadang"' prosentasiuya $24,11 \%$, dan yang menjawab "tidak pernah" adalah nihil. Sedangkan keterampilan lain yaitu menghargai pendapat orang lain walaupun pendapat itu salah. Jawaban siswa terhadap pertanyaan ini adalah "selalu" prosentasinya 37,84\%, "kadang-kadang" 45,95\% dan "tidak pernah-prosentasinya $16,22 \%$. Sementara itu aspek keterampilan berbagi pengalaman dengan sesama anggota kelompok yang menjawab "selalu" adalah 83,78\%. "kadang-kadang" 16,22\% dan menjawab "tidak pernah" 0\%. Dan aspek keterampilan menyelesaikan tugas sesuai waktu yang diberikan, siswa yang menjawab selalu prosentasinya $83,78 \%$ yang menjawab "kadang-kadang" $16,22 \%$ dan menjawab "tidak pernah" prosentasinya adalah $0 \%$.

\section{PEMBAHASAN}

Belajar secara berkelompok adalah metode mengajar dengan mengelompokan siswa menjadi beberapa kelompok untuk mengerjakan atau membahas tugas yang dibebankan kepada kelompok tersebut.Guru sebelum memulai kegiatan pembelajaran menerapkan metoda belajar secara berkelompok memberikan arahan dan penjelasan kepada siswa untuk membentuk kelompok belajar yang setiap kelompoknya tidak lebih dari 3 orang.Dalam pengarahan yang diberikan guru, siswa diberi kebebasan dan keleluasaan untuk memilih dan menentukan teman kelompoknya sendiri sesuai dengannya.Pada siklus I, dari siswa 22 yang hadir terbentuk 7 kelompok belajar.Siswa yang sudah mendapatkan teman kelompok belajar tampak raut muka yang berseri-seri, gembira dan senang, sedangkan mereka yang belum mendapatkan teman kelompoknya tampak bingung untuk memilih teman kelompoknya.Pada siklus II, dari siswa 22 yang hadir, juga terbentuk 7 kelompok belajar.Walaupun guru memberikan penjelasan dan pengarahan bahwa dalam pemilihan dan pembentukan kelompok belajar, siswa disarankan boleh untuk membentuk kelompok yang anggotanya berlainan jenis kelamin.Akan tetapi siswa nampaknya tidak mau memilih atau menentukan anggota kelompok yang berlainan 
jenis kelamin, sehingga tak satupun kelompok yang anggotanya berlainan jenis kelamin.metodebelajar kelompok menitik beratkan kepada interaksi antara anggota dalam suatu kelompok guna menyelesaikan tugas-tugas belajar secara bersama-sama(Johar Permana dan Mulyani Sumantri, 1999:148). Penekanan metode ini pada lingkungan belajar untuk bekerja sama dalam mendorong interaksi antar siswa sehingga para siswa akan dapat saling memahami dan saling menghargai satu sama lain dalam hal pandangan-pandangan atau gagasan-gagasan terhadap suatu topik pembelajaran yang akan atau sedang dibelajarkan oleh guru.

Belajar dalam kelompok merupakan usaha untuk meningkatkan atau mempertinggi aktivitas belajar siswa dalam suatu kegiatan belajar mengajar (Nana Sujana dan Daeng Arifin, 1988). Siswa sebagai subyek didik untuk terlibat aktif secara intelektual dan secara emosional sehingga belajar yang difasilitasi dan berpartisipasi dan berperan aktif dalam melakukan kegiatan belajar yang difasilitasi dan didorong oleh guru dalam suatu kegiatan belajar mengajar.Metode belajar kelompok sangat cocok digunakan pada pembelajaran IPS. Pembelajaran IPS mempelajari kehidupan sosial yang didasarkan bahan kajian geografi, ekonomi, sosiologi, antropologi, tata negara, dan "sejarah" (Depdikbud, 1994 : 15;Kurnidar et. AL, 2002).

\section{KESIMPULAN DAN SARAN}

\section{KESIMPULAN}

Kesimpulan dari hasil penelitian yang telah dilakukan adalah:

1. Pemilihan atau penetuan teman dalam membentuk kelompok belajar adalah didasarkan atas tempat duduk yang berdekatan.Teman yang duduk satu bangku dengan sendirinya menjadi teman kelompok.Kemudian pemilihan teman anggota kelompok belajar dan pemilihan satu orang teman lainnya lagi teman yang paling berdekatan dengan siswa tersebut.

2. Aktivitas belajar siswa selama mengikuti kegiatan belajar mengajar yang menerapkan metoda belajar secara berkelompok dalam mata pelajaran IPS menunjukan peningkatan.

3. Perolehan hasil belajar siswa dalam pembelajaran IPS yang menerapkan metode belajar secara berkelompok menunjukan peningkatan yang signifikan.

\section{SARAN-SARAN}

Saran yang dapat diberikan kepada guru agar dapat menggunakan metode pembelajaran ini untuk membelajarkan siswa khususnya pada mata pelajaran IPS. Guru yang akan menggunakan metode ini agar dapat mengelompokkan siswa dengan pertimbangan lain, seperti jenis kelamin, kemampuan akademik dibidang IPS, keberanian untuk berbicara dan sebagainya.

\section{DAFTAR PUSTAKA}

Departemen Pendidikan Dan Kebudayaan (1999), Penyempurnaan Penyesuaian Kurikulum1999, Jakarta, Depdikbud

Kasbolah, Kasihani, 1998, Penelitian Tindakan Kelas, Jakarta, Ditjen Dikti, Depdikbud

Permana J, dan Sumantri M, 1999, Strategi Belajar Mengajar, Jakarta, Ditjen Dikti, Depdikbud

Semiawan, Conny et. Al, 1985, Pendekatan Keterampilan Proses Bagaimana Mengaktifkan Siswa Dalam Belajar, Jakarta, PT Gramedia

Sudjana, Nana dan Arifin Daeng, 1988, Cara Belajar Siswa Aktif dalam Proses Belajar mengajar, Bandung, Sinar Baru

Kurnidar et. AL, (2002, Ilmu Pengetahuan Sosial Jilid 1: Untuk Sekolah Dasar Kelas 3 Bandung, PT Sarana Panca Karya Nusa . 